\title{
Three Principles of the Establishment of National Park System and Their Implications for China's Practice
}

\author{
Zhaoming Deng \\ Department of Finance and Economics, Graduate School of Chinese Academy of Social Sciences, Beijing, China \\ Email: dengzm86@126.com
}

Received 30 May 2016; accepted 28 June 2016; published 1 July 2016

Copyright (C) 2016 by author and Scientific Research Publishing Inc.

This work is licensed under the Creative Commons Attribution International License (CC BY).

http://creativecommons.org/licenses/by/4.0/

(c) (i) Open Access

\begin{abstract}
The idea of National Park is widely accepted in the world, which has also become a scientific measure for sustainable development. Despite of the fact that the management mechanisms of national parks in different countries may differ, there are three principles which are shared by the international national parks and to be maintained, namely, people oriented, state dominance, and adjusting measures to local conditions. People oriented is the most fundamental principle as well as the primary purpose of the construction of national park, while state dominance and adjusting measures to local conditions are two guarantees of the fulfillment of social welfare. In order to construct the Chinese national park system, China should learn from international experiences and adopt the three principles. During this transitional and learning period, China is confronted with several problems, such as "tragedy of commons", multi-sectoral management, insufficient fund etc. To deal with these issues, the current Chinese national-level parks should be carefully chosen as pilot projects, and then a unified legal system and management system should be gradually set up during this trail period. Eventually, an integrated and comprehensive Chinese National Park system should be established.
\end{abstract}

\section{Keywords}

National Park, Public Welfare, People Oriented, State Dominance, Local Conditions, Principle

\section{Introduction}

The idea of National Park has been introduced to China since the beginning of the 20th century, more than a hundred years from now. From the first attempt made by Nanjing Government of the Repulic of China in 1931, 
trying to replicate the Japanese National Park System in the Lake Taihu, to November, 2013, when "Decision of the CCCPC on Some Major Issues Concerning Comprehensively Deepening the Reform" clearly stated that our nation would establish national park system and stressed the importance of it [1], the Chinese Government had been exploring the establishment of Chinese National Park System for decades. In January 2015, "the Pilot Program of Constructing National Park System" was passed by the National Development and Reform Commission (NDRC) of China. In September of the same year, the NDRC signed a cooperative agreement with United States National Park Service regarding the construction of National Park System in China. These facts indicate that the development of China's national park has already been at a turning point and has become a critical topic that Chinese scholars in the field of tourism and heritage management can’t evade (Tian \& Yang, 2011) [2].

Some domestic scholars and research institutes propose that it is necessary for china to establish a national park system meeting with world common practice at the juncture of two centuries. However, due to the fact that the Chinese Government has been reluctant in moving this process forward, not many thorough studies regarding national park are seen in China. Wang \& Steven (2014) presented a comparative analysis of the development of the national park systems in America and China, and came to the conclusion that as an early adopter and innovator, the experience and management information accumulated about the U.S. national park system serves as a useful example for China [3]. Wu \& Liu (2015) claimed that national parks should not be considered as a few scattered nature reserves, but as an integrated system. They believed that the construction of Chinese National Park System was extremely valuable and meaningful in terms of ecological protection, national economic development, historic and cultural passing and spreading, social order stabilization and national health [4].

Nearly all Chinese scholars agree that China should learn from the successful international experience and build a national park system of our own. However, there are many aspects of a national park system, and to establish a new system is an extremely complicated and detailed task (Runte, 2010) [5]. This research aims to find the relatively simple principles of the establishment of national park system based on the international experience, which can hopefully help us get a better understanding about the National Park System and find a possible path for the construction of Chinese National Park System.

\section{Three Principles of the Construction of National Park System Based on the International Experience}

In 1872, Yellowstone, the first national park in the world, was established in the US. After that, about 5000 national parks which conform to the standard made by International Union for Conservation of Nature (the IUCN thereafter) had ever been set up in about 150 countries and regions around the world up to 2014. These statistics mean that the establishment of National Park System has become a common practice for protecting and developing the natural and cultural heritage resources in the international community. Based on the international experience, it is concluded that the construction of national park system generally has three principles: people oriented, state dominance and adjusting measures to local conditions.

\subsection{People Oriented}

People oriented is the first very basic principle and attribute for national park. According to the definition given by the IUCN, the national park was a piece of natural or near natural areas which were aimed at "protecting a wide range of ecological processes and legitimate to draw, under the premise of ensuring the survival of the species and ecosystem integrity, achieving the harmony and unity of ecological environment and spiritual cultural, scientific research, environmental education, leisure and entertainment and other functions” (IUCN, 1971) [6]. It is obvious that the main purpose of establishing the national parks is for public welfare and to achieve sustainable development of precious natural and cultural heritage resources. This is similar to what was proposed by "Recommendations for the 13th Five-Year Plan for Economic and Social Development (Recommendations for the 13th FYP thereafter)" about the Chinese citizens' status as the principal part. According to this official document, the people is the fundamental power for promoting the development, and the ultimate purpose of development is to realize, protect and maintain the fundamental interest of most people in China [7]. Once the Chinese national park system was established, the majority of high-grade scenic spots in China relying on the public resources were about to gradually transform from "quasi-public goods" to "pure public goods", meaning that their condemned government-led multi-sectoral management system as well as high ticket price are facing direct challenges. It can be foreseen that the construction of Chinese national system can not only greatly en- 
hance tourism and leisure rights of Chinese citizens, but can also have a profound impact on China's economic, social and ecological development.

\subsection{State Dominance}

The principle of state dominance mainly reflects on the unified naming system and management system for national parks. In the US, National Park Service which is affiliated to Ministry of the Interior was set up to monitor the management system of national park, while there is no right for local government to intervene the park administration. In this well-regulated system, there exist 20 different types of park units with different names, such as National Battlefields, National Historical Park, National Reserves etc. [3]. This state-steering and unified management system has two merits: on the one hand, it causes brand gathering and amplification effect. For the time-being, American national parks have been made a part of national image, some major national parks such as the Yellow Stone national park and the Grand Canyon national park have developed into world-class tourism destinations, enjoying high reputation in the international travel market; on the other hand, the citizens' right of recreation is respected and guaranteed by the government, which, along with the smartly and sophisticatedly designed patriotism education activities in the park, greatly enhance their sense of pride and affiliation. For the overseas tourists, the national parks also serve as an important window to American culture. By establishing national park system, the governments seek to strengthen national identity and to cultivate cultural confidence, which has also become a general result naturally.

\subsection{Adjusting Measures to Local Conditions}

Though the national park system originated in the US, it falls into different categories of management models, which embodies the principle of "adjusting measures to local conditions". According to Zhou, Xu, \& Zhou (2014), based on the management experience of the foreign national parks, there are generally four typical management models: centralization management model based on national identity building, co-management model driven by citizen's recreations, self-management model started from nature conservation and sustainable management model oriented by ecological tourism [8].

The first model, centralization management model based on national identity building, is adopted by America. There is a vertically unified management system in America from the NPS under the Department of Interior to its local branches. The core of this model is to set up national identity, which the American national parks are seen as a vital carrier for. The existence, operation and perfection of the national park system is guaranteed by central government's fiscal power and well-established institutional arrangement. The co-management model is a delegate with England, in which the central government is mainly in charge of coordination, guiding the multi-stakeholders to be all responsible for the park management and to share the benefits. The self-management model started form nature conservation is applied by Australia, which is connected with Australian administrative system and legislative structure. The general principle established by the nation is "nature conservation", and under the premise of without violating this principle, each state is free to choose its concrete model of management. The last model is sustainable management model oriented by ecological tourism, of which the representative countries include Japan and Finland. While fully respecting the nature, these two countries focus on exploring the ecological value of the national parks to provide their citizens with recreational opportunities.

\section{The Three Principles' Implications for China's Practice}

The three principles shed light on the essence of national park system and present the inspiration of the foreign experience for constructing the management system of Chinese national parks. Undoubtedly, establishing Chinese National Park System has its indispensable significance to the economic, ecological and social aspects, however, considering both international practice and practical situation in China, especially China's administrative pattern and problems in the management of natural heritage resources, there are several implications we should pay special attention to.

\section{1. "People Oriented" versus "Tragedy of Commons"}

"Tragedy of Commons" was first put forward by Hardin, a biology professor. The essence of this idea was that if not restricted, the human being's activities might lead to a total failure or even a disaster, even if their activi- 
ties meant no harm at first. It is not unreasonable to be vigilant about the Chinese "Tragedy of Commons" when it comes to the establishment of Chinese National Park System. First, pricing is a double-edged sword. Though some of China's heritage scenic sites, such as Wulingyuan, Huangshan Mountain, have been charging high ticket price for a long time, which has an adverse effect on the public welfare, according to the basic principle of economics, pricing also possesses certain power of controlling and limiting the number of tourist, which, to some extent, may protect the ecological landscape of the sites. Once the price fell sharply or even to zero, it can be foreseen that those high-quality scenic spots would be filled with people, which poses a rigorous challenge to the maintenance and management of the tourist attractions. Secondly, "People Oriented" means trusting and empowering tourists. In most overseas national parks, the tourist is seldom restricted, the purpose of which is to restore the purest natural and cultural experience for the visitors. However, considering the uncivilized behavior of the Chinese tourists in recent years, the national quality of China seems to be not ready to shoulder this responsibility. Last but not least, the majority of China's scenic spots, since their upstream and downstream industry chains as well as its supporting service facilities are underdeveloped, have to depend on the ticket revenue to survive. As a consequence, provided that the scenic spots truly became so-called "commons" and ticket revenue was given up, a downside of local economic fluctuations would definitely follow in a short term or even longer. How should local officials in tourism administrations be evaluated, how could we keep them enthusiastic about their work, how could we introduce market mechanism to ensure continuous supply of high-quality tourism product, and how could we make sure all the stakeholders, including the governments and companies, experts and scholars, community residents and volunteers, cooperate with each other as a team and get what they want? All these questions need to be answered, especially for those governments for whom tourism is a pillar industry.

To avoid the Chinese "Tragedy of Commons" and motivate all the stakeholders to cooperate as a team, three measures need to be taken. First, it is crucial to find enough funding for maintaining the national park system, not only from the national investment, but also from the public investors. It is not only the best way to make ends meet for the early period, but also can get more individuals involved in this enterprise. Second, it is important to adjust the assessment system for the tourism officials' career achievement. For those who engage in the administrative work of national parks, an assessment system based on the green GDP may function better than solely on the economic gain. Last, different stakeholders have different aims. Government pursues record of achievements, companies seek profits, while community residents usually worry that their normal life would be interrupted, but, in the meantime, also want to make some money out of it (Trakolis, 2001) [9]. Therefore, in order to balance different demands and to achieve sustainable development, a public participation mechanism ought to be set up, as shown in Figure 1.

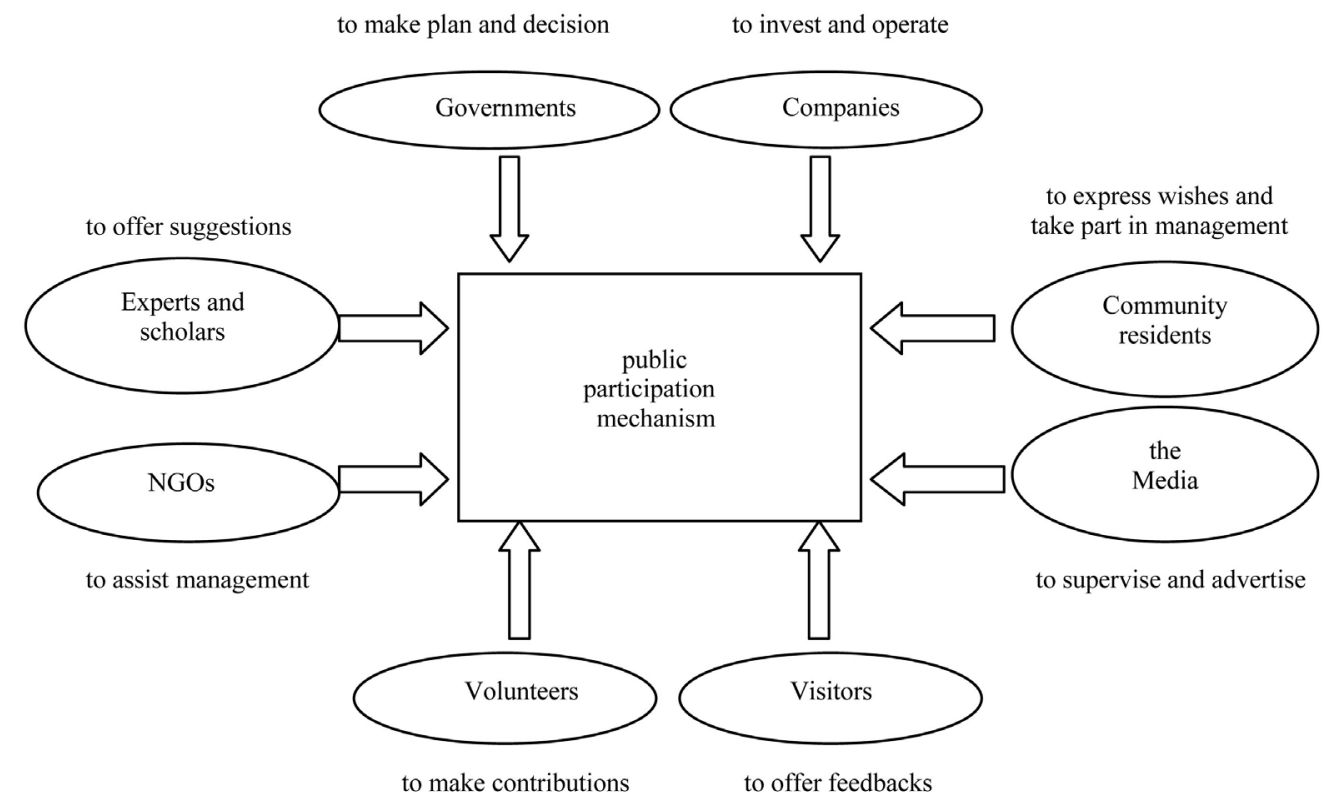

Figure 1. The establishment of public participation mechanism 
According to Figure 1, eight groups of people or organizations are identified as stakeholders in the public participation mechanism: governments, companies, experts and scholars, NGOs, community residents, the media, volunteers and visitors. Each stakeholder has their own desire and responsibility, as is stated clearly in the figure. This mechanism would function well only when all groups take their obligations and are willing to cooperate with each other.

\subsection{A Unified "State Dominance" System Is Required}

China has already established a huge national-level park system, which falls into 10 categories, namely, national nature reserve, national scenic regions, key national park, national urban wetland park, national wetland park, national forest park, national geological park, national mine park, national water park, and national archaeological site park. These parks are affiliated to six different departments that belong to the State Council, as is shown in Figure 2. The four ministries, including Ministry of Construction, Ministry of Environmental Protection, Ministry of Land Resources, and Ministry of Water Resources, are in charge of seven national-level parks, while other two departments, which are generally considered to be less powerful than the ministries, are supervisors of other three parks. The question is, these parks are not totally exclusive from the others. For instance, Wuyi Mountain, located in Fujian Province, is both a national scenic region governed by Ministry of Construction, and a national nature reserve which belongs to Ministry of Environmental Protection. In addition, it is also a national $5 \mathrm{~A}$ tourist attractions which should also be administered by National Tourism Bureau. Each administrative department has its own management system, meaning that usually the people who work in these parks have to follow numerous and various orders from several different departments, and to make it worse, these orders sometimes are contradictory to each other, thereby resulting in limited effectiveness and low efficiency.

It was suggested that China should learn from the United State by establishing a new department directly managed by the State Council: the Chinese National Park Service, and a national park management committee can be founded to be in charge of the daily affairs of the organization. However, as a late adopter, the national park system in China has already evolved in a decentralized fashion across government departments and agents, which can't be altered in a short period, together with the restriction form financial fund, it is more rational to start with pilot program [2]. First, it is suggested we choose several national-level parks which are both suitable and willing to be a part of this pilot program. Second, if the trial is successful, then we may consider promoting the national park management mechanism on a national scale. Finally, we can establish the Chinese National Park Service with a lot less resistance.

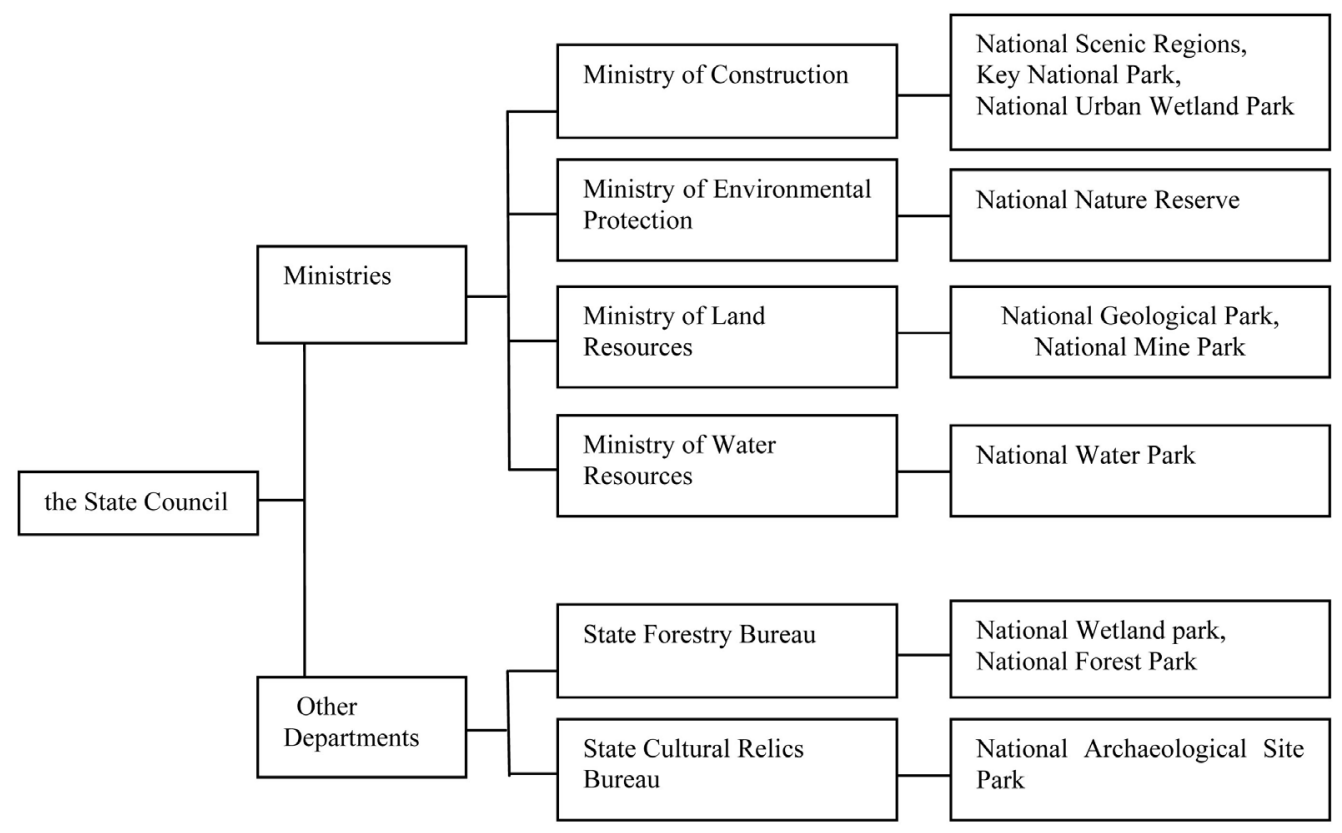

Figure 2. The national-level park system in China. 


\section{3. "Adjusting Measures to Local Conditions" Is Extremely Complicated in China}

China is a vast country with a large population, and now the world's second largest economy with a Gini coefficient close to 0.5 , indicating that there exist huge differences among different regions in terms of economic development level, regional culture, folk customs and so on. Meanwhile, as the world's largest socialist developing country, China should neither adopt the national park system of such developed countries as Britain and the U.S. blindly, nor copy the successful experience of those developing countries mechanically. In a word, we should "adjust measures to various local conditions".

Western China, a vast territory with a sparse population, has a relatively higher degree of desertification, meaning that it may fit the American model more, while in the east and central of China, the tourism attractions are more mature, which is more like the case in the England. For those provinces who already have the experience of managing national parks such as Yunnan and Helongjiang, the Australian model may be better, while for those areas where the service industry is relatively well-developed and are suitable for the tourist industry, Japan and Finland's model may have more reference value. The suggested management model for each province is show in Table 1. It is worth mentioning that, although it is listed according to the characteristics of each province, the governors should never simply copy these models, because, for one thing, there exist huge differences within the province; for another, the local ethnic customs of every park should be respected, which may require adjustment of the management system.

\section{Conclusion}

The idea of National Park is widely accepted in the world, and now it has also become a scientific measure for sustainable development, which calls for strict conservation and rational use of cultural and natural heritage resources. Based on the various conditions of different countries, four different institutional models of national parks are concluded. Despite of the fact that the management mechanisms may differ, there are three principles which are shared by the international national parks and to be maintained, namely, people oriented, state dominance, and adjusting measures to local conditions. In this new historical era, there is a major shift of China's development value from economic development-oriented to people-oriented, meaning that Chinese National Park System is facing an unprecedented development opportunity. However, this transitional period will not be an easy one because many problems exist as well, such as "tragedy of commons", multi-sectoral management, insufficient fund and so on. To tackle these problems, the current national-level parks should be carefully chosen as pilot projects, and during this trial period, a unified standard of Chinese National Park should be formulated. In the meantime, it is also crucial to set up a unified legal system and management system. Eventually, an integrated and comprehensive Chinese National Park system should be established.

Table 1. The suggested models for each province in China

\begin{tabular}{|c|c|c|c|}
\hline Type & Institutional Model & $\begin{array}{c}\text { Representative } \\
\text { Country }\end{array}$ & Province $^{\mathrm{a}}$ \\
\hline $\mathrm{I}$ & $\begin{array}{l}\text { Centralization management } \\
\text { model based on } \\
\text { national identity building }\end{array}$ & The U.S. & $\begin{array}{l}\text { Gansu Province, Qinghai Province, Inner Mongolia Autonomous } \\
\text { Region, Tibet Autonomous Region, Xinjiang Uygur Autonomous Region, } \\
\text { Ningxia Hui Autonomous Region, Liaoning Province, Jilin Province }\end{array}$ \\
\hline II & $\begin{array}{l}\text { Co-management } \\
\text { model driven by } \\
\text { citizen's recreations }\end{array}$ & England & $\begin{array}{l}\text { Shanxi Province, Hunan Province, Jiangsu Province, } \\
\text { Hubei Province, Beijing City, Tianjin City, Chongqing City, } \\
\text { Shanghai City, Hebei Province, Anhui Province }\end{array}$ \\
\hline III & $\begin{array}{l}\text { Self-management } \\
\text { model started } \\
\text { from nature conservation }\end{array}$ & Australia & $\begin{array}{l}\text { Helongjiang Province, Zhejiang Province, } \\
\text { Guizhou Province, Yunnan Province, } \\
\text { Sichuan Province, Fujian Province }\end{array}$ \\
\hline IV & $\begin{array}{l}\text { Sustainable management } \\
\text { model oriented by } \\
\text { ecological tourism }\end{array}$ & Japan, Finland & $\begin{array}{l}\text { Jiangxi Province, Shandong Province, Henan Province, } \\
\text { Guangxi Zhuang Autonomous Region, } \\
\text { Guangdong Province, Shaanxi Province }\end{array}$ \\
\hline
\end{tabular}

a. Hong Kong and Macao Special Administrative Region are not considered 


\section{Acknowledgements}

This paper was financially aid by ZTE Tourism Research Institute and Tourism Research Center of Chinese Academy of Social Sciences.

\section{References}

[1] Xinhua (2013) Decision of the CCCPC on Some Major Issues Concerning Comprehensively Deepening the Reform. http://news.xinhuanet.com/2013-11/15/c_118164235.htm

[2] Tian, S.Z. and Yang, G.H. (2011) Path Selection for the Development of China’s National Parks: International Comparison and Case Study. China Soft Science, 12, 6-14.

[3] Wang, L.Y. and Steven, H. (2014) Building a Unified Chinese National Park System: Historical Lessons Learned from the United States. Geographic Research, 33, 2407-2417.

[4] Wu, C.Z. and Liu, G.L. (2015) The Significance of the Construction of Chinese National Park. Tourism Tribune, 30, 14-16.

[5] Runte, A. (2010) National Parks: The American Experience. 4th Edition, Taylor Trade Publishing, Lanham.

[6] Lei, G.C. and Zeng, Q. (2014) Implications for National Park Construction Based on Trends of the World Conservation. Biodiversity Science, 22, 423-424.

[7] Xinhua (2015) Recommendations for the 13th Five-Year Plan for Economic and Social Development. http://news.xinhuanet.com/fortune/2015-11/03/c_1117025413.htm

[8] Zhou, W.Z., Xu, Y.Y. and Zhou, Z.C. (2015) Research on Management Models of Foreign National Parks. Journal of Shanghai Jiaotong University, 48, 1205-1202.

[9] Trakolis, D. (2001) Local People’s Perceptions of Planning and Management Issues in Prespes Lakes National Park, Greece. Journal of Environmental Management, 61, 227-241. http://dx.doi.org/10.1006/jema.2000.0410

\section{Submit or recommend next manuscript to SCIRP and we will provide best service for you:}

Accepting pre-submission inquiries through Email, Facebook, Linkedin, Twitter, etc A wide selection of journals (inclusive of 9 subjects, more than 200 journals)

Providing a 24-hour high-quality service

User-friendly online submission system

Fair and swift peer-review system

Efficient typesetting and proofreading procedure

Display of the result of downloads and visits, as well as the number of cited articles

Maximum dissemination of your research work

Submit your manuscript at: http://papersubmission.scirp.org/ 